Supporting Information for:

\title{
Modeling The Influence of Decomposing Organic Solids on Sulfate REDUCTION RATES FOR IRON PRECIPITATION
}

by

Paulo S. Hemsi ${ }^{1}$, Charles D. Shackelford ${ }^{1 *}$, and Linda A. Figueroa ${ }^{2}$

submitted to

\section{Environmental Science and Technology}

\footnotetext{
${ }^{1} \mathrm{Ph} . \mathrm{D}$. Candidate and Professor, respectively, Department of Civil Engineering, Colorado State University, Fort Collins, CO 80523-1372, USA

${ }^{2}$ Associate Professor, Division of Environmental Science and Engineering, Coolbaugh Hall, Colorado School of Mines, Golden, CO 80401-1887, USA

*Corresponding author: E: shackel@engr.colostate.edu; P: 970-491-5051; F: 970-491-3584
} 
The primary biochemical processes incorporated in the conceptual model are shown in the flowchart of Fig. S1. The primary processes pertaining to the model include (i) anaerobic decomposition of polysaccharides (cellulose/hemicellulose) in solid particulate organic materials due to the activity of decomposer bacteria, producing lactate, with hydrolysis as the rate limiting step, (ii) sulfate reduction based on the incomplete oxidation of lactate, (iii) instantaneous or kinetically controlled precipitation of ferrous iron $\left(\mathrm{Fe}^{2+}\right)$ mono-sulfide, and (iv) partial volatilization of hydrogen sulfide $\left(\mathrm{H}_{2} \mathrm{~S}\right)$ to the head-space gas phase. Although not used in the present study, additional processes of (i) sulfate reductions based on the complete oxidation of lactate and on acetate, (ii) competing lactate oxidation and methanogenesis, and (iii) dissolution/precipitation of the carbonate minerals $\mathrm{CaCO}_{3(\mathrm{~s})}$ (calcite) and $\mathrm{FeCO}_{3(\mathrm{~s})}$ (siderite) can be implemented in the model.

The comparison between simulated and experimental results performed in this study is based on the temporal trends in $\mathrm{SO}_{4}{ }^{2-}, \mathrm{Fe}^{2+}$, and $\mathrm{H}_{2} \mathrm{~S}$ concentrations. In addition, the simulated behaviors of organic solid materials, dissolved organic substrates, and different bacterial populations are evaluated. The methodology consisted of applying the mathematical model considering only the primary processes to approximate $\mathrm{SO}_{4}{ }^{2-}, \mathrm{Fe}^{2+}$, and $\mathrm{H}_{2} \mathrm{~S}$ trends in the different sets of experimental data, inputting and adjusting parameter values based on the literature for each process in the model during model calibration with the experimental data.

\section{MODEL VARIABLES, PARAMETERS, AND MASS YIELD COEFFICIENTS}

\section{Primary Model Processes:}

Model Variables:

$\left[\mathrm{CE}_{\mathrm{i}}\right]$ : decomposable polysaccharide concentration $(\mathrm{i}=1 . . \mathrm{n}) . \mathrm{n}$ : total number of polysaccharide materials in the system.

$\left[\mathrm{X}_{\mathrm{d}, \mathrm{i}}\right]$ : biomass concentration of decomposer bacteria $(\mathrm{i}=1 . . \mathrm{n})$.

[LA]: concentration of lactate.

$\left[\mathrm{X}_{\mathrm{SRB} 1}\right]$ : biomass concentration of sulfate-reducing bacteria 1 . 
[SO]: concentration of sulfate.

$\left[\mathrm{H}_{2} \mathrm{~S}\right]$ : concentration of hydrogen sulfide in solution.

$\left[\mathrm{H}_{2} \mathrm{~S}\right]_{\mathrm{g}}$ : concentration of hydrogen sulfide in the gas phase.

[FE]: concentration of ferrous iron.

[FES]: concentration of iron-sulfide precipitate.

[A]: concentration of acetate.

t: time.

Parameters:

$\mathrm{k}_{\mathrm{f}, \mathrm{i}}$ : First-order rate coefficient for decomposition of polysaccharide ' $\mathrm{i}$ '.

$\mathrm{k}_{\mathrm{c}, \mathrm{i}}$ : Contois rate coefficient for decomposition of polysaccharide ' $\mathrm{i}$ '.

$\mathrm{K}_{\mathrm{c}, \mathrm{i}}$ : Contois half saturation coefficient for decomposition of polysaccharide ' $\mathrm{i}$ '.

$d_{d, i}$ : First-order rate coefficient for decay of decomposer bacteria ' $i$ '.

$\mu_{\mathrm{SRB} 1}$ : Monod maximum specific growth rate of $\mathrm{SRB}_{1}$.

$\mathrm{K}_{\mathrm{V} 1}$ : Monod half-saturation coefficient for lactate in sulfate reduction 1.

$\mathrm{K}_{\mathrm{SO} 1}$ : Monod half-saturation coefficient for sulfate in sulfate reduction 1.

$\mathrm{d}_{1}$ : First-order rate coefficient for decay of $\mathrm{SRB}_{1}$.

$\mathrm{k}_{\mathrm{FeS}}$ : First-order precipitation rate coefficient for the solid FeS.

$\mathrm{k}_{\mathrm{v}}$ : First-order volatilization rate coefficient for $\mathrm{H}_{2} \mathrm{~S} \rightarrow \mathrm{H}_{2} \mathrm{~S}_{(\mathrm{g})}$.

$\mathrm{K}$ : Dimensionless Henry's law coefficient for $\mathrm{H}_{2} \mathrm{~S} \rightarrow \mathrm{H}_{2} \mathrm{~S}_{(\mathrm{g})}$.

Mass yield coefficients:

$\mathrm{Y}_{\mathrm{Xd} / \mathrm{CE}}$ : mass yield coefficient for decomposer bacteria / polysaccharide, $=0.1827$

$\mathrm{g} / \mathrm{g}$.

$\mathrm{Y}_{\mathrm{LA} / \mathrm{CE}}$ : mass yield coefficient for lactate / polysaccharide, $=0.8588 \mathrm{~g} / \mathrm{g}$.

$\mathrm{Y}_{\mathrm{SO} / \mathrm{SRB} 1}$ : mass yield coefficient for sulfate $/ \mathrm{SRB}_{1},=11.097 \mathrm{~g} / \mathrm{g}$.

$\mathrm{Y}_{\mathrm{HS} / \mathrm{SRB} 1}$ : mass yield coefficient for $\mathrm{H}_{2} \mathrm{~S} / \mathrm{SRB}_{1},=3.9350 \mathrm{~g} / \mathrm{g}$.

$\mathrm{Y}_{\mathrm{LA} / \mathrm{SRB} 1}$ : mass yield coefficient for lactate $/ \mathrm{SRB}_{1},=21.880 \mathrm{~g} / \mathrm{g}$.

$\mathrm{Y}_{\mathrm{A} / \mathrm{SRB} 1}$ : mass yield coefficient for acetate $/ \mathrm{SRB}_{1},=13.632 \mathrm{~g} / \mathrm{g}$.

$\mathrm{Y}_{\mathrm{HCO} / \mathrm{SRB} 1}$ : mass yield coefficient for $\mathrm{HCO}_{3} / \mathrm{SRB}_{1},=14.089 \mathrm{~g} / \mathrm{g}$.

$\mathrm{Y}_{\mathrm{FES} / \mathrm{HS}}$ : mass yield coefficient for $\mathrm{FeS} / \mathrm{H}_{2} \mathrm{~S}$ in precipitation, $=2.5811 \mathrm{~g} / \mathrm{g}$.

$\mathrm{Y}_{\mathrm{FE} / \mathrm{HS}}$ : mass yield coefficient for ferrous iron $/ \mathrm{H}_{2} \mathrm{~S}$ in precipitation, $=1.6397$

$\mathrm{g} / \mathrm{g}$.

CONCEPTUAL BASIS FOR THE MODEL, AND BIOCHEMICAL AND KINETIC EQUATIONS

\section{Primary Biochemical-Reactivity Processes}

\section{Polysaccharide Hydrolysis}

Decomposition of solid organic materials has been observed to be the rate-limiting step in bacterial sulfate reduction (S1, S2, S3, S4, S5, S6, S7). Polysaccharides (cellulose and 
hemicellulose) occur in large amounts (e.g., $\sim 60-70 \%$ by dry weight) in plant residues of woods, straw, and leaves, and are susceptible to anaerobic decomposition (S8, S9, S10, S11, S12, S13, S14). Hydrolysis is promoted by the activity of a consortium of microorganisms, facilitated by extracellular enzymes, and generally observed to be the rate-limiting step in the anaerobic decomposition of organic solids, including plant residues, decomposing municipal solid waste, and wastewater solids (S10, S12, S15, S16, S17, S18, S7, S19). Therefore, the homogenous reactions occurring after hydrolysis (cellobiose $\rightarrow$ glucose $\rightarrow$ volatile fatty acids) are assumed not to be kinetically limiting, and the rate of lactate production is assumed as directly proportional to the rate of polysaccharide hydrolysis. In contrast with complex, more mechanistic hydrolysis models (e.g., S20, S21, S16, S22), the relatively simple first-order and the Contois kinetic models are frequently used in the simulation of anaerobic digestion of organic matter (e.g., S23, S24, S15, S25, S26, S27, S28, S29, S19). These less mechanistic, simpler models often are preferred because these models can provide an average yet relatively accurate representation of decomposition over time without the requirement for detailed and extensive input parameter values (S15, S27, S28), and consist of simple kinetic expressions that incorporate cumulative effects of different processes (S27, S19).

Based on the first-order model, the rate of polysaccharide decomposition is given as follows:

$$
\frac{\mathrm{d}\left[\mathrm{CE}_{\mathrm{i}}\right]}{\mathrm{dt}}=-\mathrm{k}_{\mathrm{f}, \mathrm{i}}\left[\mathrm{CE}_{\mathrm{i}}\right] \frac{1}{1+\left(\left[\mathrm{LA}_{\mathrm{u}}\right] / \mathrm{K}_{\mathrm{i}}\right)^{\mathrm{m}_{\mathrm{i}}}}
$$

where $\left[\mathrm{CE}_{\mathrm{i}}\right]$ is the concentration of decomposable polysaccharide ' $\mathrm{i}$ ' in terms of dry mass of 
decomposable polysaccharide per volume of solution, $\left[\mathrm{LA}_{\mathrm{u}}\right]$ is the concentration of undissociated lactic acid, $\mathrm{k}_{\mathrm{f}, \mathrm{i}}$ is a rate coefficient $(1 / \mathrm{T})$, and $\mathrm{K}_{\mathrm{i}}$ and $\mathrm{m}_{\mathrm{i}}$ are the inhibition constant and degree index, respectively. Based on the assumption that undissociated organic acids will be negligible for systems opperating within the $\mathrm{pH}$ range for the model, the resulting first-order expression can be written as follows:

$$
\frac{\mathrm{d}\left[\mathrm{CE}_{\mathrm{i}}\right]}{\mathrm{dt}}=-\mathrm{k}_{\mathrm{f}, \mathrm{i}}\left[\mathrm{CE}_{\mathrm{i}}\right]
$$

In terms of Contois kinetics (S30), the rate of polysaccharide decomposition is proportional to the concentration of decomposer bacteria associated with the decomposable material, and regulated by the ratio between the concentrations of decomposable polysaccharide and bacteria, as follows:

$$
\frac{\mathrm{d}\left[\mathrm{CE}_{\mathrm{i}}\right]}{\mathrm{dt}}=-\mathrm{k}_{\mathrm{c}, \mathrm{i}}\left[\mathrm{X}_{\mathrm{d}, \mathrm{i}}\right] \frac{\left(\left[\mathrm{CE}_{\mathrm{i}}\right] /\left[\mathrm{X}_{\mathrm{d}, \mathrm{i}}\right]\right)}{\mathrm{K}_{\mathrm{c}, \mathrm{i}}+\left(\left[\mathrm{CE}_{\mathrm{i}}\right] /\left[\mathrm{X}_{\mathrm{d}, \mathrm{i}}\right]\right)}
$$

where $\left[\mathrm{X}_{\mathrm{d}, \mathrm{i}}\right]$ is the biomass concentration of decomposer bacteria ' $\mathrm{i}$ ' associated with material ' $\mathrm{i}$ ', $\mathrm{k}_{\mathrm{c}, \mathrm{i}}$ is a rate coefficient $(1 / \mathrm{T})$, and $\mathrm{K}_{\mathrm{c}, \mathrm{i}}$ is a Contois affinity constant. This expression transitions between the two limiting cases of first-order kinetics with respect to $\left[\mathrm{CE}_{\mathrm{i}}\right]$ at low $\left[\mathrm{CE}_{\mathrm{i}}\right] /\left[\mathrm{X}_{\mathrm{d}, \mathrm{i}}\right]$ ratios, and first-order kinetics with respect to $\left[\mathrm{X}_{\mathrm{d}, \mathrm{i}}\right]$ at high $\left[\mathrm{CE}_{\mathrm{i}}\right] /\left[\mathrm{X}_{\mathrm{d}, \mathrm{i}}\right]$ ratios (i.e., exponential $\mathrm{X}_{\mathrm{d}, \mathrm{i}}$ growth). A rate coefficient such as $\mathrm{k}_{\mathrm{c}, \mathrm{i}}$ lumps the effects of intrinsic material degradability and particle gradation (i.e., surface area) that would be included in more mechanistic approaches 
(e.g., S21).

Equation S.2 or S.3 represents the slowest step in polysaccharide decomposition to generate lactate and, therefore, the rates of lactate production in solution and $\mathrm{X}_{\mathrm{d}, \mathrm{i}}$ growth are taken simply as proportional to $\mathrm{d}\left[\mathrm{CE}_{\mathrm{i}}\right] / \mathrm{dt}$, as follows:

$$
\frac{\mathrm{d}[\mathrm{LA}]}{\mathrm{dt}}=\mathrm{Y}_{\mathrm{LA} / \mathrm{CE}} \sum_{\mathrm{i}=1}^{\mathrm{n}}\left(-\frac{\mathrm{d}\left[\mathrm{CE}_{\mathrm{i}}\right]}{\mathrm{dt}}\right)
$$

and

$$
\frac{d\left[X_{d, i}\right]}{d t}=Y_{X d / C E}\left(-\frac{d\left[\mathrm{CE}_{i}\right]}{d t}\right)-d_{d, i}\left[X_{d, i}\right]
$$

where $[\mathrm{LA}]$ is the concentration of lactate, $\mathrm{Y}_{\mathrm{LA} / \mathrm{CE}}$ is the mass-yield coefficient for LA (mass of LA produced per gram of polysaccharide decomposed), $\mathrm{n}$ is the total number of decomposable materials incorporated in the system, $\mathrm{Y}_{\mathrm{Xd} / \mathrm{CE}}$ is the mass-yield coefficient for $\mathrm{X}_{\mathrm{d}, \mathrm{i}}$ (mass of $\mathrm{X}_{\mathrm{d}, \mathrm{i}}$ produced per gram of polysaccharide decomposed), and $d_{d, i}$ is the first-order bacterial decay rate $(1 / T)$. Decomposer bacteria gain energy and grow from the transformation of glucose into fatty acids (S20). However, since this step is not limiting, the growth rate ultimately depends on the rate of the heterogeneous reaction, and a Monod expression representing the growth of $\mathrm{X}_{\mathrm{d}, \mathrm{i}}$ based on glucose is not required.

As presented, mass-yield coefficients for LA and $\mathrm{X}_{\mathrm{d}, \mathrm{i}}$ are assumed invariable with $\mathrm{CE}_{\mathrm{i}}$ (i.e., are assumed the same for different decomposable polysaccharide residues). The values of $\mathrm{Y}_{\mathrm{LA} / \mathrm{CE}}$ and $\mathrm{Y}_{\mathrm{Xd} / \mathrm{CE}}$ are obtained from sequential stoichiometries as follows: 


$$
\mathrm{n} \underbrace{\left(\mathrm{C}_{6} \mathrm{H}_{10} \mathrm{O}_{5}\right)}_{\text {cellulose }}+\mathrm{H}_{2} \mathrm{O} \rightarrow(\mathrm{n}-2)\left(\mathrm{C}_{6} \mathrm{H}_{10} \mathrm{O}_{5}\right)+\underbrace{\mathrm{C}_{12} \mathrm{H}_{22} \mathrm{O}_{11}}_{\text {cellobiose }}
$$

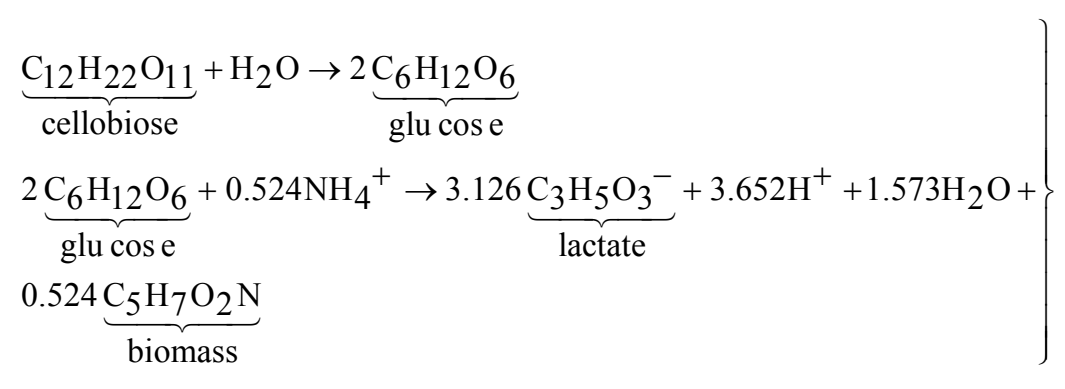

resulting in $\mathrm{Y}_{\mathrm{LA} / \mathrm{CE}}=0.8588 \mathrm{~g} / \mathrm{g}$, and $\mathrm{Y}_{\mathrm{Xd} / \mathrm{CE}}=0.1827 \mathrm{~g} / \mathrm{g}$. The formula for cellulose is assumed as representative of the bulk of the decomposable solids, and the formula for biomass (e.g., S26) is a simplified form of possible more complete formulas including, for example, $\mathrm{S}$ and $\mathrm{P}$, such as $\mathrm{C}_{5} \mathrm{H}_{7} \mathrm{O}_{2} \mathrm{NS}_{0.1} \mathrm{P}_{0.06}($ e.g., $\mathrm{S} 31)$.

\section{Sulfate Reduction Based on Incomplete Lactate Oxidation}

The rate of sulfate reduction is limited by the availability of dissolved (i.e., utilizable) organic substrates for the growth of sulfate reducing bacteria (SRB) released in solution from decomposition of solid organic materials. The volatile fatty acids are produced upon solid decomposition and are the major SRB substrates (S32, S33). The major and most abundant genera of SRB are incomplete oxidizers of lactate and propionate (lumped in the model as lactate) (S34, S35, S36, S6, S7), examples of which include Desulfovibrio, Desulfotomaculum, and Desulfomonas (S37, S34). This SRB category is heretofore designated as $\mathrm{SRB}_{1}$.

The growth of $\mathrm{SRB}_{1}$ is modeled using Monod kinetics (S38), as previously adopted for sulfate reduction on limiting dissolved substrates (e.g., S39, S33, S40, S41). Dual-substrate Monod expressions representing SRB growth limited by lactate and $\mathrm{SO}_{4}{ }^{2-}$, and including a first- 
order bacterial decay term, are written as follows:

$$
\frac{\mathrm{d}\left[\mathrm{X}_{\mathrm{SRB}_{1}}\right]}{\mathrm{dt}}=\mu_{\mathrm{SRB}_{1}}\left[\mathrm{X}_{\mathrm{SRB}_{1}}\right]\left(\frac{[\mathrm{LA}]}{\mathrm{K}_{\mathrm{V} 1}+[\mathrm{LA}]}\right)\left(\frac{[\mathrm{SO}]}{\mathrm{K}_{\mathrm{SO} 1}+[\mathrm{SO}]}\right)-\mathrm{d}_{1}\left[\mathrm{X}_{\mathrm{SRB}_{1}}\right]
$$

where $\left[\mathrm{X}_{\mathrm{SRB} 1}\right]$ is the biomass concentration of $\mathrm{SRB}_{1}(\mathrm{mg} / \mathrm{L}),[\mathrm{SO}]$ is the concentration of $\mathrm{SO}_{4}{ }^{2-}$, [LA] is the concentration of lactate, $\mu_{\mathrm{SRB} 1}$ is the maximum specific growth rate for $\mathrm{SRB}_{1}$ on $\mathrm{LA}$ $(1 / \mathrm{T}), \mathrm{K}_{\mathrm{V} 1}$ is the half-saturation coefficient for $\mathrm{LA}$, and $\mathrm{K}_{\mathrm{SO} 1}$ is the half-saturation coefficient for $\mathrm{SO}_{4}{ }^{2-}$. The first-order rate coefficient, $\mathrm{d}_{1}$, corresponds to $\mathrm{SRB}_{1}$ decay $(1 / \mathrm{T})$. The kinetic expression for lactate (LA) combines solid decomposition and sulfate reduction 1 . The term accounting for LA consumption is directly linked to $\mathrm{SRB}_{1}$ growth using a mass yield coefficient, and the resulting expression is written as follows:

$$
\left.\begin{array}{rl}
\frac{\mathrm{d}[\mathrm{LA}]}{\mathrm{dt}} & =\mathrm{Y}_{\mathrm{LA} / \mathrm{CE}} \sum_{\mathrm{i}=1}^{\mathrm{n}}\left(-\frac{\mathrm{d}\left[\mathrm{CE}_{\mathrm{i}}\right]}{\mathrm{dt}}\right) \\
& -\mathrm{Y}_{\mathrm{LA} / \mathrm{SRB} 1} \mu_{\mathrm{SRB}_{1}}\left[\mathrm{X}_{\mathrm{SRB}_{1}}\right]\left(\frac{[\mathrm{LA}]}{\mathrm{K}_{\mathrm{V} 1}+[\mathrm{LA}]}\right)\left(\frac{[\mathrm{SO}]}{\mathrm{K}_{\mathrm{SO} 1}+[\mathrm{SO}]}\right)
\end{array}\right\}
$$

where $\mathrm{Y}_{\mathrm{LA} / \mathrm{SRB} 1}$ is the mass-yield coefficient for $\mathrm{LA}$ with respect to growth of $\mathrm{SRB}_{1}$.

The kinetic expressions for $\mathrm{SO}_{4}{ }^{2-}, \mathrm{H}_{2} \mathrm{~S}, \mathrm{HCO}_{3}{ }^{-}$, and acetate consumed/produced in sulfate reduction 1 also are linked to $\mathrm{SRB}_{1}$ growth as follows:

$$
\frac{\mathrm{d}[\mathrm{c}]}{\mathrm{dt}}=\mathrm{Y}_{\mathrm{c} / \mathrm{SRB} 1} \mu_{\mathrm{SRB}_{1}}\left[\mathrm{X}_{\mathrm{SRB}_{1}}\right]\left(\frac{[\mathrm{LA}]}{\mathrm{K}_{\mathrm{V} 1}+[\mathrm{LA}]}\right)\left(\frac{[\mathrm{SO}]}{\mathrm{K}_{\mathrm{SO} 1}+[\mathrm{SO}]}\right)
$$


where [c] represents the concentration of either $\mathrm{SO}_{4}{ }^{2-}, \mathrm{H}_{2} \mathrm{~S}, \mathrm{HCO}_{3}{ }^{-}$, or acetate, and $\mathrm{Y}_{\mathrm{c} / \mathrm{SRB} 1}$ is the mass yield coefficient corresponding to species c. For $\mathrm{SO}_{4}{ }^{2-}, \mathrm{Y}_{\mathrm{c} / \mathrm{SRB} 1}=-\mathrm{Y}_{\mathrm{SO} / \mathrm{SRB} 1}$, and for $\mathrm{H}_{2} \mathrm{~S}$, $\mathrm{HCO}_{3}{ }^{-}$, and acetate, $\mathrm{Y}_{\mathrm{c} / \mathrm{SRB} 1}=+\mathrm{Y}_{\mathrm{HS} / \mathrm{SRB} 1},+\mathrm{Y}_{\mathrm{HCO} / \mathrm{SRB} 1},+\mathrm{Y}_{\mathrm{A} / \mathrm{SRB} 1}$, respectively. Mass-yield coefficients are obtained assuming the following sulfate reduction stoichiometry (S42):

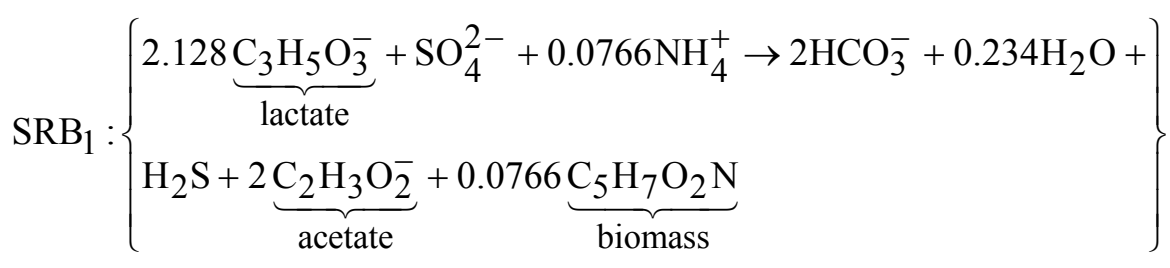

which leads to $\mathrm{Y}_{\mathrm{LA} / \mathrm{SRB} 1}=21.880 \mathrm{~g} / \mathrm{g}, \mathrm{Y}_{\mathrm{SO} / \mathrm{SRB} 1}=11.097 \mathrm{~g} / \mathrm{g}, \mathrm{Y}_{\mathrm{HS} / \mathrm{SRB} 1}=3.935 \mathrm{~g} / \mathrm{g}, \mathrm{Y}_{\mathrm{HCO} / \mathrm{SRB} 1}=$ $14.089 \mathrm{~g} / \mathrm{g}$, and $\mathrm{Y}_{\mathrm{A} / \mathrm{SRB} 1}=13.632 \mathrm{~g} / \mathrm{g}$.

\section{Precipitation of Heavy-Metal Sulfides}

The model considers heavy-metal mono sulfides (i.e., 1:1 metal to $\mathrm{S}^{2-}$ on an atomic mole basis) as the stoichiometric form of the sulfide precipitate, which is in agreement with the observed formation of amorphous $\mathrm{FeS}$ and an approximation for mackinawite $\left(\mathrm{FeS}_{0.9}\right)$ (e.g., S43, S44, S45, S46). The model is capable of handling multiple heavy metals of concern, such as $\mathrm{Fe}^{2+}, \mathrm{Cd}^{2+}, \mathrm{Cu}^{2+}, \mathrm{Pb}^{2+}$, and $\mathrm{Zn}^{2+}$, commonly associated with contaminated aquifers impacted by AMD in the western U.S.A. (www.epa.gov/region08). The equilibrium reaction for the precipitation/dissolution of a generic heavy-metal mono-sulfide $\left(\mathrm{MS}_{\mathrm{k}}\right)$ can be written as follows:

$$
\mathrm{M}_{\mathrm{k}}^{2+}+\mathrm{H}_{2} \mathrm{~S} \underset{\mathrm{k}_{\mathrm{d}, \mathrm{k}}}{\stackrel{\mathrm{k}_{\mathrm{p}, \mathrm{k}}}{\rightleftarrows}} \mathrm{MS}_{\mathrm{k}(\mathrm{s})}+2 \mathrm{H}^{+}
$$


where $\mathrm{M}_{\mathrm{k}}{ }^{2+}$ is any divalent generic heavy metal, and $\mathrm{k}_{\mathrm{d}, \mathrm{k}}$ and $\mathrm{k}_{\mathrm{p}, \mathrm{k}}$ are the dissolution and precipitation rate coefficients for $\mathrm{MS}_{\mathrm{k}}$, respectively.

The net rate of precipitation of $\mathrm{MS}_{\mathrm{k}}$ (i.e., $\mathrm{r}_{\mathrm{p}, \mathrm{k}}^{\text {net }}$ ) is obtained by subtracting the rate of dissolution (i.e., $\mathrm{r}_{\mathrm{d}, \mathrm{k}}$ ) from the rate of precipitation (i.e., $\mathrm{r}_{\mathrm{p}, \mathrm{k}}$ ) as follows (S47):

$$
\mathrm{r}_{\mathrm{p}, \mathrm{k}}^{\mathrm{net}}=\underbrace{\mathrm{k}_{\mathrm{p}, \mathrm{k}}\left[\mathrm{M}_{\mathrm{k}}\right]\left[\mathrm{H}_{2} \mathrm{~S}\right]}_{\mathrm{r}_{\mathrm{p}, \mathrm{k}}}-\underbrace{\mathrm{k}_{\mathrm{d}, \mathrm{k}}\left[\mathrm{H}^{+}\right]^{2}}_{\mathrm{r}_{\mathrm{d}, \mathrm{k}}}
$$

where $\mathrm{k}_{\mathrm{p}, \mathrm{k}}$ and $\mathrm{k}_{\mathrm{d}, \mathrm{k}}$ are the precipitation and dissolution rate coefficients, respectively. Additionally, the solubility product for $\mathrm{MS}_{\mathrm{k}}$ can be written as follows:

$$
\mathrm{K}_{\mathrm{sp}, \mathrm{k}}=\frac{\mathrm{k}_{\mathrm{d}, \mathrm{k}}}{\mathrm{k}_{\mathrm{p}, \mathrm{k}}}=\frac{\mathrm{r}_{\mathrm{d}, \mathrm{k}} /\left[\mathrm{H}^{+}\right]^{2}}{\mathrm{r}_{\mathrm{p}, \mathrm{k}} /\left[\mathrm{M}_{\mathrm{k}}\right]\left[\mathrm{H}_{2} \mathrm{~S}\right]}
$$

The rate coefficient $\mathrm{k}_{\mathrm{d}, \mathrm{k}}$ can be eliminated from Eq. S.13 by combining with Eq. S.14, or:

$$
\mathrm{r}_{\mathrm{p}, \mathrm{k}}^{\text {net }}=\mathrm{k}_{\mathrm{p}, \mathrm{k}} \mathrm{K}_{\mathrm{sp}, \mathrm{k}}\left[\mathrm{H}^{+}\right]^{2}\left\{\frac{\left[\mathrm{M}_{\mathrm{k}}\right]\left[\mathrm{H}_{2} \mathrm{~S}\right] /\left[\mathrm{H}^{+}\right]^{2}}{\mathrm{~K}_{\mathrm{sp}, \mathrm{k}}}-1\right\}
$$

where the net rate of precipitation is expressed as a function of the super saturation of the solution with respect to $\mathrm{M}_{\mathrm{k}}$ and $\mathrm{H}_{2} \mathrm{~S}$. At equilibrium, the net rate of precipitation is zero. However, the SR system is assumed not to be at equilibrium with the solid phase (i.e., for each 
time step, a new aliquot of $\mathrm{H}_{2} \mathrm{~S}$ is release by sulfate reduction, and a new aliquot of $\mathrm{MS}_{\mathrm{k}}$ is formed). Also, the dissolution of $\mathrm{MS}_{\mathrm{k}}$ during the operational life of the SR system is neglected, resulting in the following simplified equation for the precipitation of $\mathrm{MS}_{\mathrm{k}}$ :

$$
\mathrm{r}_{\mathrm{p}, \mathrm{k}}^{\mathrm{net}}=\mathrm{k}_{\mathrm{p}, \mathrm{k}}\left[\mathrm{M}_{\mathrm{k}}\right]\left[\mathrm{H}_{2} \mathrm{~S}\right]
$$

Finally, the rate coefficient for precipitation can be defined in terms of the concentration $(\mathrm{mg} / \mathrm{L})$ of $\mathrm{H}_{2} \mathrm{~S}$ consumed, and the kinetics can be written as follows:

$$
\begin{aligned}
& \frac{\mathrm{d}\left[\mathrm{H}_{2} \mathrm{~S}\right]}{\mathrm{dt}}=-\sum_{\mathrm{k}=1}^{\mathrm{m}} \mathrm{k}_{\mathrm{k}}\left[\mathrm{M}_{\mathrm{k}}\right]\left[\mathrm{H}_{2} \mathrm{~S}\right] \\
& \frac{\mathrm{d}\left[\mathrm{M}_{\mathrm{k}}\right]}{\mathrm{dt}}=-\mathrm{Y}_{\mathrm{k}} / \mathrm{HS}_{\mathrm{k}}\left[\mathrm{M}_{\mathrm{k}}\right]\left[\mathrm{H}_{2} \mathrm{~S}\right] \\
& \frac{\mathrm{d}\left[\mathrm{MS}_{\mathrm{k}}\right]}{\mathrm{dt}}=\mathrm{Y}_{\mathrm{MS}_{\mathrm{k}} / \mathrm{HS} \mathrm{k}_{\mathrm{k}}\left[\mathrm{M}_{\mathrm{k}}\right]\left[\mathrm{H}_{2} \mathrm{~S}\right]}
\end{aligned}
$$

where $k_{k}$ is the rate coefficient for precipitation in terms of $\mathrm{H}_{2} \mathrm{~S}$, and $=k_{\mathrm{p}, \mathrm{k}} / \mathrm{Y}_{\mathrm{MSk} / \mathrm{HS}}, \mathrm{Y}_{\mathrm{Mk} / \mathrm{HS}}$ and $Y_{M S k / H S}$ are mass-yield coefficients for $M_{k}$ and $M_{k}$ with respect to $H_{2} S$, and $m$ is the total number of heavy metals in the system. The kinetics of $\mathrm{H}_{2} \mathrm{~S}$ including production (sulfate reduction) and precipitation are as follows: 


$$
\left.\begin{array}{rl}
\frac{\mathrm{d}\left[\mathrm{H}_{2} \mathrm{~S}\right]}{\mathrm{dt}} & =\mathrm{Y}_{\mathrm{HS} / \mathrm{SRB} 1} \mu_{\mathrm{SRB}_{1}}\left[\mathrm{X}_{\mathrm{SRB}_{1}}\right]\left(\frac{[\mathrm{LA}]}{\mathrm{K}_{\mathrm{V} 1}+[\mathrm{LA}]}\right)\left(\frac{[\mathrm{SO}]}{\mathrm{K}_{\mathrm{SO} 1}+[\mathrm{SO}]}\right) \\
& -\sum_{\mathrm{k}=1}^{\mathrm{m}} \mathrm{k}_{\mathrm{k}}\left[\mathrm{M}_{\mathrm{k}}\right]\left[\mathrm{H}_{2} \mathrm{~S}\right]
\end{array}\right\}
$$

As the value of the precipitation rate coefficient $\left(\mathrm{k}_{\mathrm{k}}\right)$ increases, precipitation approaches the limiting case of an instantaneous process. Apart from kinetically-controlled precipitation, an alternative consideration in the model is the use of an instantaneous precipitation algorithm, with the basic algorithm given below:

$$
\begin{aligned}
& \text { - if } \left.\left[\mathrm{H}_{2} \mathrm{~S}\right]^{\mathrm{t}}<[\mathrm{FE}]^{\mathrm{t}} \text {, then } \begin{array}{l}
{[\mathrm{FE}]^{\mathrm{t}+1}=[\mathrm{FE}]^{\mathrm{t}}-\left[\mathrm{H}_{2} \mathrm{~S}\right]^{\mathrm{t}} \mathrm{Y}_{\mathrm{FE} / \mathrm{HS}}} \\
{[\mathrm{FES}]^{\mathrm{t}+1}=[\mathrm{FES}]^{t}+\left[\mathrm{H}_{2} \mathrm{~S}\right]^{\mathrm{t}} \mathrm{Y}_{\mathrm{FES} / \mathrm{HS}}} \\
{\left[\mathrm{H}_{2} \mathrm{~S}\right]^{\mathrm{t}+1}=0}
\end{array}\right\}
\end{aligned}
$$

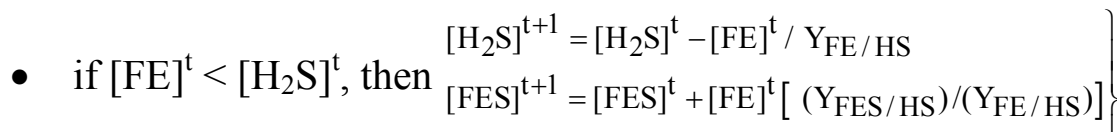

$$
\begin{aligned}
& {[\mathrm{FE}]^{\mathrm{t}+1}=0}
\end{aligned}
$$

where the variables and mass yield coefficients have been defined before, and the superscripts " $\mathrm{t}$ " and " $\mathrm{t}+1$ " denote present and future integration time steps. The first condition, i.e., $\mathrm{H}_{2} \mathrm{~S}$ in solution being limiting to FeS precipitation, is generally the case in the SR system.

\section{Partial Volatilization of Hydrogen Sulfide}

The partial volatilization of $\mathrm{H}_{2} \mathrm{~S}$ to the gas phase requires the presence of liquid-gas interfaces within the SR system. In this case, the equilibrium reaction for the mass transfer can be written as follows: 


$$
\mathrm{H}_{2} \mathrm{~S}_{(1)}^{\mathrm{o}} \underset{\mathrm{k}_{\mathrm{s}}}{\stackrel{\mathrm{k}_{\mathrm{v}}}{\rightleftarrows}} \mathrm{H}_{2} \mathrm{~S}_{(\mathrm{g})}
$$

where $\mathrm{k}_{\mathrm{v}}$ and $\mathrm{k}_{\mathrm{s}}$ are the rate coefficients of volatilization and gas solubilization, respectively.

The net rate of $\mathrm{H}_{2} \mathrm{~S}$ volatilization to the gas phase can be obtained by subtracting the rate of gas solubilization from the rate of volatilization as follows:

$$
\mathrm{r}_{\mathrm{v}}^{\text {net }}=\mathrm{k}_{\mathrm{v}}\left[\mathrm{H}_{2} \mathrm{~S}\right]-\mathrm{k}_{\mathrm{s}}\left[\mathrm{H}_{2} \mathrm{~S}\right]_{(\mathrm{g})}
$$

where the net rate $\mathrm{r}_{\mathrm{v}}{ }^{\text {net }}$ corresponds to the net rate of $\mathrm{H}_{2} \mathrm{~S}$ loss from solution (i.e., $=-\mathrm{d}\left[\mathrm{H}_{2} \mathrm{~S}\right] / \mathrm{dt}$ ). If the concentrations in the two phases are at equilibrium, then $r_{v}{ }^{\text {net }}=0$, and the dimensionless Henry's law coefficient, $\mathrm{K}\left(=\mathrm{k}_{\mathrm{v}} / \mathrm{k}_{\mathrm{s}}\right)$ at $25^{\circ} \mathrm{C}$ for $\mathrm{H}_{2} \mathrm{~S}$ is $0.42(\mathrm{~S} 48)$ or $0.53(\mathrm{~S} 26)$. However, for concentrations in the two phases that are not at equilibrium, the kinetic rates of mass transfer are given as follows (e.g., S12, S48, S28):

$$
\frac{\mathrm{d}\left[\mathrm{H}_{2} \mathrm{~S}\right]}{\mathrm{dt}}=-\mathrm{k}_{\mathrm{v}}\left\{\left[\mathrm{H}_{2} \mathrm{~S}\right]-\frac{\left[\mathrm{H}_{2} \mathrm{~S}\right]_{(\mathrm{g})}}{\mathrm{K}}\right\}
$$

and

$$
\frac{\mathrm{d}\left[\mathrm{H}_{2} \mathrm{~S}\right](\mathrm{g})}{\mathrm{dt}}=-\frac{\mathrm{V}_{1}}{\mathrm{~V}_{\mathrm{g}}}\left(\frac{\mathrm{d}\left[\mathrm{H}_{2} \mathrm{~S}\right]}{\mathrm{dt}}\right)
$$

where $\left[\mathrm{H}_{2} \mathrm{~S}\right]_{(\mathrm{g})} / \mathrm{K}$ represents the liquid-phase concentration $\left[\mathrm{H}_{2} \mathrm{~S}\right]$ that would be at equilibrium 
with the gas phase concentration $\left[\mathrm{H}_{2} \mathrm{~S}\right]_{(\mathrm{g})}$, and $\mathrm{V}_{1} / \mathrm{V}_{\mathrm{g}}$ is the volume ratio (liquid phase/gas phase).

If the gas phase is assumed to be vented to the atmosphere, then $\mathrm{V}_{\mathrm{g}} \rightarrow:\left(\mathrm{V}_{\mathrm{l}} / \mathrm{V}_{\mathrm{g}} \rightarrow 0\right),\left[\mathrm{H}_{2} \mathrm{~S}\right]_{\mathrm{g}}$ remains equal to zero at all times, and the rate of mass loss from the liquid phase is a maximum, as given by the following expression:

$$
\frac{\mathrm{d}\left[\mathrm{H}_{2} \mathrm{~S}\right]}{\mathrm{dt}}=-\mathrm{k}_{\mathrm{v}}\left[\mathrm{H}_{2} \mathrm{~S}\right]
$$

Apart from kinetically-controlled $\mathrm{H}_{2} \mathrm{~S}$ volatilization, an alternative consideration in the model is the use of an instantaneous volatilization algorithm, requiring the input of a venting frequency. The basic algorithm is given below:

$$
\left\{\begin{array}{l}
{\left[\mathrm{H}_{2} \mathrm{~S}\right]^{\mathrm{t}+1}=\left[\mathrm{H}_{2} \mathrm{~S}\right]^{\mathrm{t}}+\frac{\left[\mathrm{H}_{2} \mathrm{~S}\right]_{(\mathrm{g})}^{\mathrm{t}}}{\left(\frac{\mathrm{V}_{1}}{\mathrm{~V}_{\mathrm{g}}}+\mathrm{K}\right)}-\frac{\frac{\mathrm{V}_{\mathrm{g}}}{\mathrm{V}_{\mathrm{l}}}}{\left(1+\frac{\mathrm{V}_{\mathrm{g}}}{\mathrm{V}_{\mathrm{l}}} \mathrm{K}\right)}\left[\mathrm{H}_{2} \mathrm{~S}\right]^{\mathrm{t}}} \\
{\left[\mathrm{H}_{2} \mathrm{~S}\right]_{(\mathrm{g})}^{\mathrm{t}+1}=\left[\mathrm{H}_{2} \mathrm{~S}\right]_{(\mathrm{g})}^{\mathrm{t}}+\frac{\left[\mathrm{H}_{2} \mathrm{~S}\right]^{\mathrm{t}}}{\left(\frac{\mathrm{V}_{\mathrm{g}}}{\mathrm{V}_{\mathrm{l}}}+\frac{1}{\mathrm{~K}}\right)}-\frac{\frac{\mathrm{V}_{\mathrm{g}}}{\mathrm{V}_{\mathrm{g}}} \frac{1}{\mathrm{~K}}}{\left(1+\frac{\mathrm{V}_{\mathrm{l}}}{\mathrm{Vg}} \frac{1}{\mathrm{~K}}\right)}\left[\mathrm{H}_{2} \mathrm{~S}\right]_{(\mathrm{g})}^{\mathrm{t}}}
\end{array}\right.
$$

where the variables have been defined before, and the superscripts " $\mathrm{t}$ " and " $\mathrm{t}+\mathrm{l}$ " denote present and future integration time steps.

\section{MASS BALANCES IN THE BATCH SYSTEM}

Mass Balance Equations 
Species mass balances are written considering a fixed-volume transient batch reactor operated with mixing and with no input or output fluxes (i.e., not replenished, and neglecting the effects of sampling). For any given species, the rate of mass accumulation/removal in the reactor is equal to the rate of mass utilization (i.e., production/consumption) within the reactor due to the reactivity of the SR system, or (e.g., S49, S26):

$$
\frac{\mathrm{dM}_{\mathrm{i}}}{\mathrm{dt}}=\mathrm{V} \frac{\mathrm{d}\left[\mathrm{c}_{\mathrm{i}}\right]}{\mathrm{dt}}=\mathrm{Vr}_{\mathrm{ut}, \mathrm{i}}
$$

where $\mathrm{V}$ is the volume of the reactor, $\mathrm{M}_{\mathrm{i}}$ and $\left[\mathrm{c}_{\mathrm{i}}\right]$ are the mass and concentration of a generic species, respectively, and $r_{u t, i}$ is the temporal rate of utilization (in terms of concentrations) of the species due to the reactivity within the SR reactor.

After canceling V from both sides of Eq. S.28, mass balance equations for each species are identical to the equations corresponding to the kinetic rates of utilization, which have been described for all species in the SR system in the proceeding items.

\section{MATHEMATICAL BASIS AND SOLUTION FOR THE MODEL}

Thus, the model solution will require the simultaneous solution over time of several interdependent species mass balance equations (one for each chemical or biological species). Considering ' $n$ ' chemical and biological species in the system, the mathematical model will consist of a system of ' $n$ ' non-linear and non-steady state ordinary differential equations (ODEs) in terms of species concentrations, along with a set of ' $n$ ' selected initial conditions and several parameter values for the model processes. The system of equations can be written in the following general form: 


$$
\left.\begin{array}{l}
\frac{d\left[c_{1}\right]}{d t}=f_{1}\left(t,\left[c_{1}\right],\left[c_{2}\right], \ldots,\left[c_{i}\right], \ldots,\left[c_{n}\right]\right) \\
\frac{d\left[c_{2}\right]}{d t}=f_{2}\left(t,\left[c_{1}\right],\left[c_{2}\right], \ldots,\left[c_{i}\right], \ldots,\left[c_{n}\right]\right) \\
\vdots \\
\frac{d\left[c_{i}\right]}{d t}=f_{i}\left(t,\left[c_{1}\right],\left[c_{2}\right], \ldots,\left[c_{i}\right], \ldots,\left[c_{n}\right]\right) \\
\vdots \\
\frac{d\left[c_{n}\right]}{d t}=f_{n}\left(t,\left[c_{1}\right],\left[c_{2}\right], \ldots,\left[c_{i}\right], \ldots,\left[c_{n}\right]\right)
\end{array}\right\}
$$

where each equation is a mass balance expression for a chemical or biological species, with the functions ' $f_{1}, f_{2}, \ldots, f_{n}$ ' corresponding to the biochemical kinetic functions accounting for the model processes that affect the concentration of the species in the system, as seen before. These functions are generally superimposed for each species, i.e., added using mass yield coefficients to form an expression governing the fate of the species in the system. Mass yield coefficients for any given biochemical process may be positive (representing source, or production, of the species due to the process), negative (representing sink, or consumption), or null (representing no effect).

The numerical solution to the system of equations is obtained by simultaneous integration of the system in time, starting from initial conditions $(t=0)$. Point-wise numerical evaluations of functional values $\left[\mathrm{c}_{\mathrm{i}}\right]$ at future time levels, i.e., $\left[\mathrm{c}_{\mathrm{i}}\right](\mathrm{t}+\Delta \mathrm{t})$ for each $\left[\mathrm{c}_{\mathrm{i}}\right]$ in the system, are accomplished with the Runge-Kutta-Fehlberg (RKF) numerical-integration method (S50), encoded for this study using Compaq Visual Fortran 6.0. This method consists of performing two independent Runge-Kutta numerical integrations, one of fifth order and one of fourth order, at each time step using coefficients developed by Cash and Karp as described elsewhere (S50). This procedure allows for the evaluation of relative local truncation errors affecting newly 
calculated $\left[\mathrm{c}_{\mathrm{i}}\right](\mathrm{t}+\Delta \mathrm{t})$ values over time for each species based on the two Runge-Kutta predictors of different orders. The local truncation error affecting the generic function $\left[\mathrm{c}_{\mathrm{i}}\right]$ at integration time ' $\mathrm{t}+\Delta \mathrm{t}$ ' can be written as follows:

$$
E_{i}(t+\Delta t)=\frac{\left|\left[c_{i}\right]^{r k 5}(t+\Delta t)-\left[c_{i}\right]^{r k 4}(t+\Delta t)\right|}{\left[c_{i}\right]^{r k 5}(t+\Delta t)}
$$

where $E_{i}$ is the error affecting species ' $i$ ' at the specified time level, and superscripts 'rk5' and 'rk4' imply the fifth- and fourth-order Runge-Kutta evaluations of the function, respectively. The margins of errors for each species must be $\leq 5 \times 10^{-6} \mathrm{mg} / \mathrm{L}$ per $1.0 \mathrm{mg} / \mathrm{L}$ in order for the simulation to be valid.

When instantaneous precipitation and/or volatilization are considered, the equations for selected species (e.g., $\mathrm{Fe}^{2+}, \mathrm{H}_{2} \mathrm{~S}$, and $\mathrm{FeS}$, in the case of precipitation) are modified by omitting the process kinetic term which in this case is replaced by code lines corresponding to the instantaneous processes, added within the main time loop of the RKF algorithm, after the evaluation of $\left[\mathrm{c}_{\mathrm{i}}\right]^{\mathrm{rk} 5}(\mathrm{t}+\Delta \mathrm{t})$ and $\left[\mathrm{c}_{\mathrm{i}}\right]^{\mathrm{rk} 4}(\mathrm{t}+\Delta \mathrm{t})$, and therefore modifying the concentration values of species involved in the processes.

Apart from the kinetic terms representing kinetically controlled precipitation of metal sulfide and volatilization of $\mathrm{H}_{2} \mathrm{~S}$ to the gas phase that can be used in the model, the algorithm for instantaneous precipitation of $\mathrm{FeS}$ is based on equilibrium, and usually $\mathrm{H}_{2} \mathrm{~S}$ in solution limits precipitation. The algorithm for instantaneous partial volatilization of $\mathrm{H}_{2} \mathrm{~S}$ to the head-space gas phase also is based on equilibrium, assuming that the head-space gas phase of a reaction flask has a constant volume that is equal to a known fraction of the liquid-phase volume, and is vented 
periodically following a known venting frequency (i.e., gas escapes, flask is closed with null gasphase $\mathrm{H}_{2} \mathrm{~S}$, and mass transfer occurs).

\section{LOCAL TRUNCATION ERRORS AND ELEMENTAL MASS CONSERVATION}

Relative local truncation errors (Eq. S.30) are evaluated over time for each species in each batch test based on the Runge Kutta predictors utilized in the numerical algorithm. For batch test 1 (case $1 \mathrm{~b}$, Table 3), the truncation errors versus time for cellulose, decomposer bacteria, SRB, and lactate are shown in Fig. S2a, and the errors for $\mathrm{SO}_{4}{ }^{2-}, \mathrm{H}_{2} \mathrm{~S}, \mathrm{Fe}^{2+}$, and precipitate are shown in Fig. S2b. For batch test 3 (case 3a), the truncation errors for the two polysaccharide materials, the two decomposer bacteria, SRB, and lactate are shown in Fig. S3a, and the errors for $\mathrm{SO}_{4}{ }^{2-}, \mathrm{H}_{2} \mathrm{~S}, \mathrm{Fe}^{2+}$, and precipitate and shown in Fig. S3b. Plots of the errors in batch tests 2 and 4 are not shown to avoid repetition.

The range of errors for polysaccharides, decomposer bacteria, SRB, lactate, $\mathrm{H}_{2} \mathrm{~S}$, and precipitate are equal to, or limited by, the value of $1 \times 10^{-6} \mathrm{mg} / \mathrm{L}$ per $1.0 \mathrm{mg} / \mathrm{L}$, except for a maximum value of $\sim 5 \times 10^{-6} \mathrm{mg} / \mathrm{L}$ per $1.0 \mathrm{mg} / \mathrm{L}$ observed for polysaccharides and SRB in Fig. S3a. These ranges are considered acceptable in this study. In the case of $\mathrm{SO}_{4}{ }^{2-}$ and $\mathrm{Fe}^{2+}$, the truncation errors are observed to increase as the species approach the point of depletion from the batch system, which corresponds to the denominator of Eq. S.30 approaching zero. As the concentrations of $\mathrm{SO}_{4}{ }^{2-}$ and $\mathrm{Fe}^{2+}$ decline from $100 \%$ to $<0.5 \%$ of the initial values, the relative errors increase from $\sim 1 \times 10^{-8} \mathrm{mg} / \mathrm{L}$ per $1.0 \mathrm{mg} / \mathrm{L}$ to $\sim 1 \times 10^{-4} \mathrm{mg} / \mathrm{L}$ per $1.0 \mathrm{mg} / \mathrm{L}$. Since the higher level of errors is associated with very low percentages of the initial concentrations (i.e., depletion of the species from the system), this range of errors also is assumed acceptable in this study. 
Verifications of elemental mass conservation within the batch systems over time were performed after all simulations. Given the biochemical transformations occurring in the systems, and the fact that the systems are not replenished, elemental mass conservations for total iron, sulfur, and carbon (i.e., with respect to the initial elemental mass added at the beginning of the simulation) must be respected at all times. Figure S4 illustrates the mass conservation of iron, sulfur, and carbon in the simulation of batch test 1 (case 1b). The plots show the elemental mass distribution into different species over time on the primary y-axis (i.e., left-hand side y-axis) and the "mass balance" verification on the secondary y-axis (i.e., right-hand side y-axis) over time. For example, the sulfur mass distribution includes the species $\mathrm{SO}_{4}{ }^{2-}, \mathrm{H}_{2} \mathrm{~S}$, and FeS at all times (see primary $\mathrm{y}$-axis of Figure $\mathrm{S} 4 \mathrm{~b}$ ). The "mass balance" axis identification refers to a ratio between the total elemental mass (of iron, sulfur, or carbon) accounted in the system at any time, with respect to the total mass initially added. As shown in Figures S4a and b, elemental mass balances for iron and sulfur were very accurate (i.e., ratio $=1.0$ ). As observable in Figure S4c, the

elemental carbon mass balance ranged from 1.0 to 0.91 , which was assumed as acceptable. In all other batch simulations, the levels of carbon mass balance were similar to those in batch test 1 .

\section{LITERATURE CITED}

(S1) Tuttle, J.H.; Dugan, P.R.; Randles, C.I. Microbial sulfate reduction and its potential utility as an acid mine water pollution abatement procedure. Applied Microbiology 1969, 17 (2), 297-302.

(S2) Lovley, D.R.; Klug, M.J. Model for the distribution of sulfate reduction and methanogenesis in freshwater sediments. Geochimica et Cosmochimica Acta 1986, 50 (1), 11-18.

(S3) Westrich, J.T.; Berner, R.A. The role of sedimentary organic matter in bacterial sulfate reduction: the G model tested. Journal of Limnology and Oceanography 1984, 29 (2), 236249. 
(S4) Bechard, G.; Yamazaki, H.; Gould, W.D.; Bedard, P. Use of cellulosic substrates for the microbial treatment of acid mine drainage. Journal of Environmental Quality 1994, 23 (1), 111-116.

(S5) Drury, J.W. Modeling of sulfate reduction in anaerobic solid substrate bioreactors for mine drainage treatment. Mine Water and the Environment 2000, 19 (1), 18-28.

(S6) Chang, I.S.; Shin, P.K.; Kim, B.H. Biological treatment of acid mine drainage under sulphate-reducing conditions with solid waste materials as substrates. Water Research 2000, 34 (4), 1269-1277.

(S7) Logan, M.; Ahamann, D.; Figueroa, L. Assessment of microbial activity in anaerobic columns treating synthetic mine drainage. In Proceedings of the 2003 Annual Meeting of the American Society for Mining and Reclamation; American Society for Mining and Reclamation: Lexington, KY, 2003.

(S8) Stephens, G.R.; Heichel, G.H. Agricultural and forest products as sources of cellulose. In Cellulose as a Chemical and Energy Resource; C.R. Wilke, Ed., John Wiley and Sons: New York, NY, 1975.

(S9) Fan, L.T.; Gharpuray, M.M; Lee, Y.H. Cellulose Hydrolysis. Springer-Verlag, Berlin, Germany, 1987.

(S10) Jain, S.; Lala, A.; Bhatia, S.; Kudchadker, A. Modeling of hydrolysis controlled anaerobic digestion. Journal of Chemical Technology and Biotechnology 1992, 53 (4), 337-344.

(S11) Owens, J.M.; Chynoweth, D.P. Biochemical methane potential of municipal solid waste (MSW) components. Water Science and Technology 1993, 27 (2), 1-14. 
(S12) Chynoweth, D.P.; Pullammanappallil, P. Anaerobic digestion of municipal solid waste. In Microbiology of Solid Waste, A. Palmasano and M.A. Barlaz, Eds.,CRC Press: Boca Raton, FL, 1996.

(S13) Micales, J.A.; Skog, K.E. The decomposition of forest products in landfills. International Biodeterioration and Biodegradation 1997, 39 (2-3), 145-158.

(S14) Sylvia, D.M.; Fuhmann, J.J.; Hartel, P.G.; Zuberer, D.A. Principles and Applications of Soil Microbiology; Prentice Hall: Upper Saddle River, New Jersey, NJ, 1998.

(S15) Vavilin, V.A.; Rytov, S.V.; Lokshina, L. A description of hydrolysis kinetics in anaerobic degradation of particulate organic matter. Bioresource Technology 1996, 56 (1), 229-237.

(S16) Lai, T.E.; Pullammanappallil, P. A mathematical model for hydrolysis of cellulosic substrate. In Proceedings of the Second Asia-Pacific Conference on Sustainable Energy and Environmental Technologies, G.Q. Lu, V. Rudolph, and P.F. Greenfield, Eds., University of Queensland Press: Brisbane, Australia, 1998.

(S17) Lai, T.E.; Nopharatana, A.; Pullammanappallil, P.; Clarke, W. Cellulolytic activity in leachate during leach-bed anaerobic digestion of municipal solid waste. Bioresource Technology 2001, 80 (3), 205-210.

(S18) Lynd, L.; Weimer, P.; van Zyl, W.; Pretorius, I. Microbial cellulose utilization: fundamentals and biotechnology. Microbiology and Molecular Biology Reviews 2002, 66 (3), 506-577.

(S19) Vavilin, V.A.; Lokshima, L.; Jokela, J.; Rintala, J. Modeling solid waste decomposition. Bioresource Technology 2004, 94 (1), 69-81. 
(S20) Humphrey, A. E. The Hydrolysis of Cellulosic Materials to Useful Products. In Hydrolysis of Cellulose: Mechanisms of Enzymatic and Acid Catalysis, Chapter 2, Advances in Chemistry Series, No. 181, American Chemical Society: Washington D.C., 1979.

(S21) Negri, E.D.; Mata-Alvarez, J.; Sans, C.; Cecchi, F. A mathematical model of volatile fatty acids production in a plug flow reactor treating the organic fraction of municipal solid waste. In Proceedings of the International Symposium on Anaerobic Digestion of Solid Waste, Venice, 14-17 April, Stamperia de Venezia: Venice, Italy, 1992.

(S22) Batstone, D.J.; Keller, J.; Newell, R.; Newland, M. Modeling anaerobic degradation of complex wastewater: I model development. Bioresource Technology 2000, 75 (1), 67-74.

(S23) Vasiliev, V.B.; Vavilin, V.A.; Rytov, S.V.; Ponomarev, A.V. Simulation model of anaerobic digestion of organic matter by a microorganism consortium: basic equations. Water Resources 1993, 20 (6), 714-725.

(S24) Gujer, W.; Henze, M.; Mino, T.; Matsuo, T.; Wentzel, M.; Maraist, G. The activated sludge model No. 2: biological phosphorous removal. Water Science and Technology 1995, $31(2), 1-11$.

(S25) Bagley, D.M.; Brodkorb, T.S. Modeling microbial kinetics in an anaerobic sequencing batch reactor-model development and experimental validation. Water Environment Research 1999, 71 (7), 1320-1332.

(S26) Rittman, B.E.; McCarty, P.L. Environmental Biotechnology: Principles and Applications. McGraw-Hill: NewYork, NY, 2001.

(S27) Vavilin, V.A.; Rytov, S.; Lokshina, L.; Rintala, J.; Lyberatos, G. Simplified hydrolysis models for the optimal design of two-stage anaerobic digestion. Water Research 2001, 35 (17), $4247-4251$. 
(S28) Batstone, D.J.; Keller, J.; Angelidaki, I.; Kalyuzhnyi, S.; Pavlostathis, S.; Rozzi, A.;

Sanders, W.; Siegrist, H.; Vavilin, V.A. The IWA anaerobic digestion model No. 1 (ADM1). Water Science and Technology 2002, 45 (10), 65-73.

(S29) Vavilin, V.A.; Rytov, S.; Lokshima, L.; Pavlostathis, S.; Barlaz, M. Distributed model of solid waste anaerobic digestion-effects of leachate recirculation and $\mathrm{pH}$ adjustment. Biotechnology and Bioengineering 2003, 81 (1), 66-73.

(S30) Contois, D.E. Kinetics of bacterial growth, relationship between population density and specific growth rate of continuous cultures. Journal of General Microbiology 1959, 21 (1), 40-50.

(S31) Speece, R.E. Anaerobic Biotechnology for Industrial Wastewaters. Archae Press: Nashville, TN, 1996.

(S32) Schönheit, P.; Krisjansson, J. K.; Thauer, R. K. Kinetic mechanism for the ability of sulfate reducers to out-compete methanogens for acetate. Archives of Microbiology 1982, $132(3), 285-288$.

(S33) Ingvorsen, K.; Zehnder, A. J.; Jorgensen, B. Kinetics of sulfate uptake by Desulfobacter postgatei. Applied and Environmental Microbiology 1984, 47 (2), 403-408.

(S34) Widdel, F. Microbiology and ecology of sulfate reducing bacteria., In Biology of Anaerobic Microorganisms. Chapter 10, A. J. B. Zehnder, Ed. Wiley Interscience: New York, NY, 1988.

(S35) Langmuir, D. Aqueous Environmental Geochemistry. Prentice-Hall: Upper Saddle River, NJ, 1997. 
(S36) Schafer, D.; Schafer, W.; Kinzelbach, W. Simulation of reactive processes related to biodegradation in aquifers. 2-model application to a column study on organic carbon degradation. Journal of Contaminant Hydrology 1998, 31 (1-2), 187-209.

(S37) Postgate, J.R. The Sulphate-Reducing Bacteria. $2^{\text {nd }}$ Edition. Cambridge University Press: Cambridge, UK, 1984.

(S38) Monod, J. The growth of bacterial cultures. Annual Review of Microbiology 1949, 3, 371394.

(S39) Middleton, A.C.; Lawrence, A.W. Kinetics of microbial sulfate reduction. Journal of Water Pollution Control Federation 1977, 49 (7), 1659-1670.

(S40) Okane, S.; Nielsen, P.H.; Jones, W.L.; Characklis, W.G. Rate and stoichiometry of microbial sulfate reduction by Desulfovibrio desulfuricans in biofilms. Biofouling 1995, 9 (1), 63-83.

(S41) Konishi, Y.; Yoshida, N.; Asai, S. Desorption of hydrogen sulfide during batch growth of the sulfate-reducing bacterium Desulfovibrio desulfuricans. Biotechnology Progress 1996, 12 (3), 322-330.

(S42) Kim, S.D.; Kilbane, J.J.; Cha, D.K. Prevention of acid mine drainage by sulfate reducing bacteria: organic substrate addition to mine waste piles. Environmental Engineering Science 1999, $16(2), 139-145$.

(S43) Benner, S.G.; Blowes, D.W.; Gould, W.D.; Herbert, R.B.; Ptacek, C. J. Geochemistry of a permeable reactive barrier for metals and acid mine drainage, Environmental Science and Technology 1999, 33 (16), 2793-2799. 
(S44) Waybrant, K.R.; Blowes, D.W.; Ptacek, C.J. Selection of reactive mixtures for use in permeable reactive walls for treatment of mine drainage. Environmental Science and Technology 1998, 32 (13), 1972-1979.

(S45) Waybrant, K.R.; Ptacek, C.J.; Blowes, D.W. Treatment of mine drainage using permeable reactive barriers: column experiments. Environmental Science and Technology 2002, 36 (6), 1349-1356.

(S46) Hulshof, A.H.; Blowes, D.W.; Ptacek, C.J.; Gould, W.D. Microbial and nutrient investigations into the use of in situ layers for treatment of tailings effluent. Environmental Science and Technology 2003, 37 (21), 5027-5033.

(S47) Morel, F.M.M.; Hering, J.G. Principles and Applications of Aquatic Chemistry. John Wiley and Sons: New York, NY, 1993.

(S48) Valsaraj, K.T. Elements of Environmental Engineering - Thermodynamics and Kinetics. $2^{\text {nd }}$ Edition, Lewis Publishers: Boca Raton, FL, 2000.

(S49) Rittmann, B.E.; VanBriesen, J.M. Microbiological processes in reactive modeling. Reactive Transport in Porous Media Reviews in Mineralogy 1996, 34, 311-334.

(S50) Chapra, S.C.; Canale, R.P. Numerical Methods for Engineers, $4^{\text {th }}$ Edition; McGraw-Hill: New York, NY, 2002. 


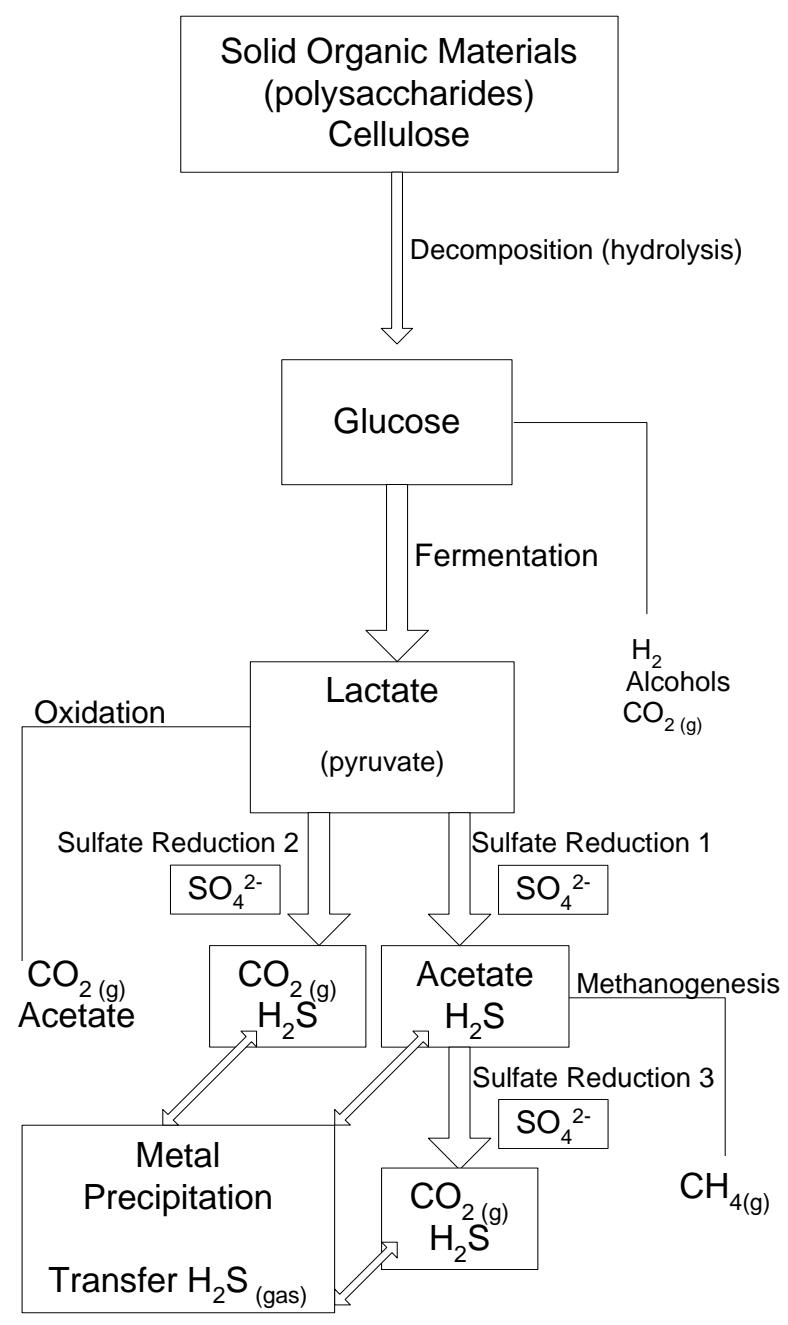

Figure S1 - Flowchart of the primary biochemical processes in the conceptual model. 

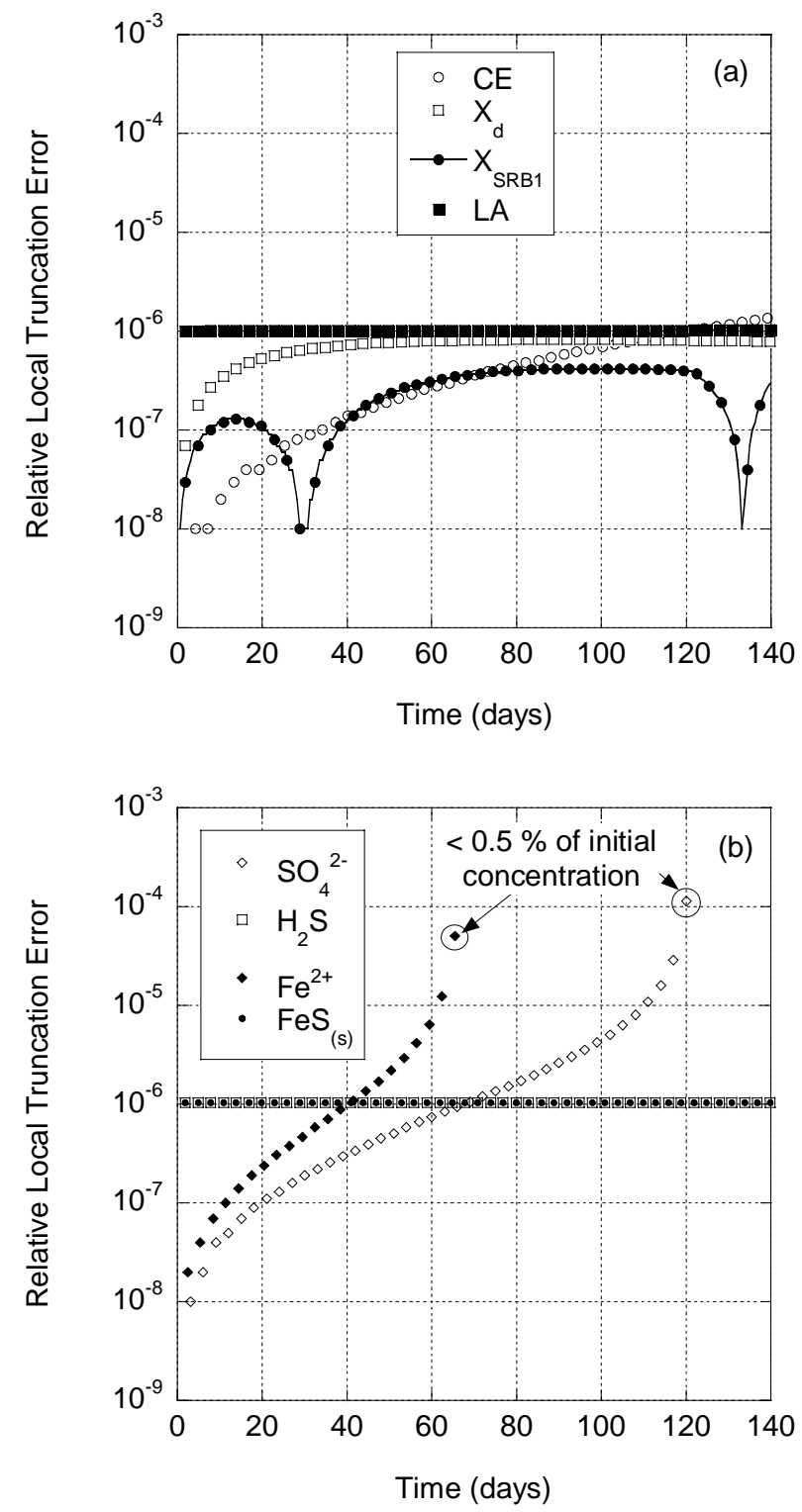

Figure S2 - Relative local truncation error in batch test 1 (Case 1b): (a) cellulose (CE), decomposer bacteria $\left(\mathrm{X}_{\mathrm{d}}\right)$, sulfate-reducing bacteria $\left(\mathrm{X}_{\mathrm{SRB} 1}\right)$, and lactate $(\mathrm{LA})$, and (b) sulfate $\left(\mathrm{SO}_{4}{ }^{2-}\right)$, hydrogen sulfide $\left(\mathrm{H}_{2} \mathrm{~S}\right)$, ferrous iron $\left(\mathrm{Fe}^{2+}\right)$, and ferrous iron sulfide $\left(\mathrm{FeS}_{(\mathrm{s})}\right)$. 

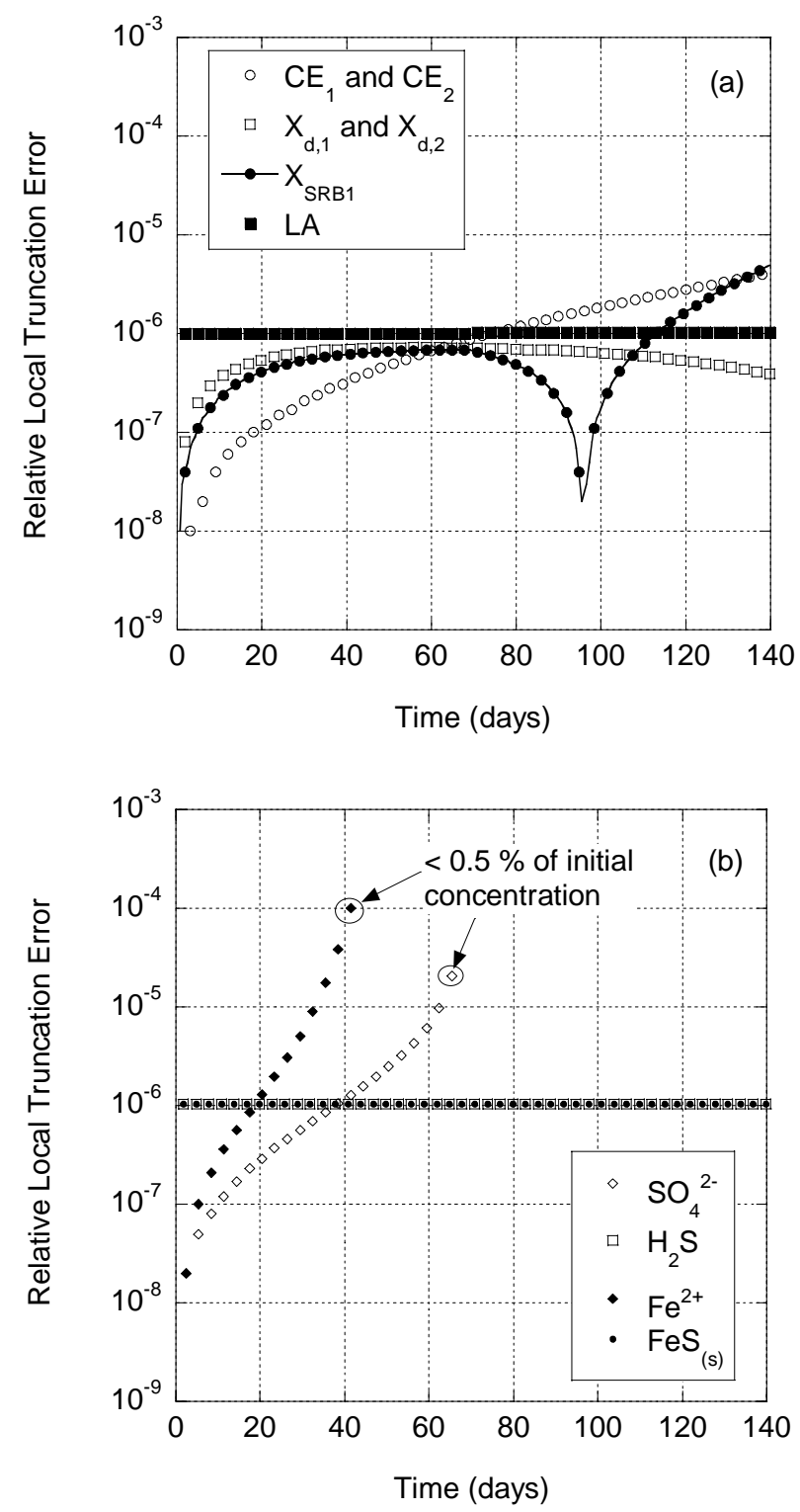

Figure S3 - Relative local truncation error in batch test 3 (Case 3a): (a) polysaccharides $\left(\mathrm{CE}_{1}\right.$ and $\left.\mathrm{CE}_{2}\right)$, decomposer bacteria $\left(\mathrm{X}_{\mathrm{d}, 1}\right.$ and $\left.\mathrm{X}_{\mathrm{d}, 2}\right)$, sulfate-reducing bacteria $\left(\mathrm{X}_{\mathrm{SRB} 1}\right)$, and lactate (LA), and (b) sulfate $\left(\mathrm{SO}_{4}{ }^{2-}\right)$, hydrogen sulfide $\left(\mathrm{H}_{2} \mathrm{~S}\right)$, ferrous iron $\left(\mathrm{Fe}^{2+}\right)$, and ferrous iron sulfide $\left(\mathrm{FeS}_{(\mathrm{s})}\right)$. 

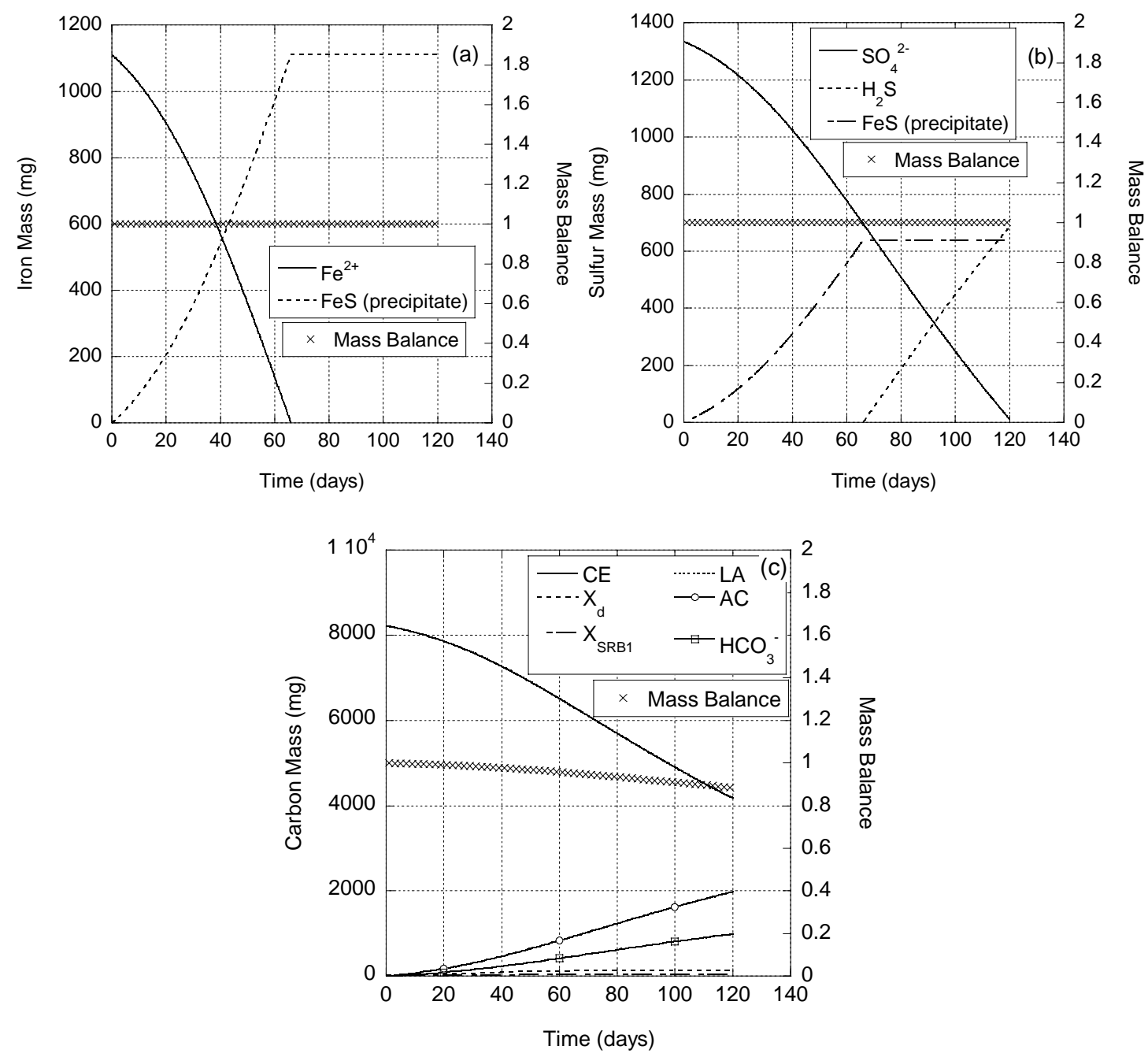

Figure S4 - Examples of elemental mass conservation verifications in batch test 1 (Case 1b) (a) iron, (b) sulfur, and (c) carbon. Polysaccharide (CE), decomposer bacteria $\left(\mathrm{X}_{\mathrm{d}}\right)$, sulfate-reducing bacteria $\left(\mathrm{X}_{\mathrm{SRB} 1}\right)$, lactate (LA), acetate (AC), bicarbonate $\left(\mathrm{HCO}_{3}{ }^{-}\right)$, sulfate $\left(\mathrm{SO}_{4}{ }^{2-}\right)$, hydrogen sulfide $\left(\mathrm{H}_{2} \mathrm{~S}\right)$, ferrous iron $\left(\mathrm{Fe}^{2+}\right)$, and ferrous iron sulfide $(\mathrm{FeS})$. 